\title{
Insulin-like growth factors and their binding proteins in the ovine oviduct during the oestrous cycle
}

\author{
K. R. Stevenson and D. C. Wathes* \\ Department of Farm Animal and Equine Medicine and Surgery. The Royal Veterinary College, \\ Boltons Park, Hawkshead Road, Potters Bar, Herts EN6 1NB, UK
}

\begin{abstract}
The oviduct is the site of fertilization, and factors present in the oviductal fluid appear to be crucial to the future success of conceptus development. The spatial and temporal localization of mRNA encoding components of the insulin-like growth factor (IGF) system (IGF-I, IGF-II, the type I IGF receptor, and IGF-binding proteins $-2,-3$ and -4 ) in the ovine oviduct were examined in tissue samples taken during the early and late stages of follicular development, and the early, mid-, and late luteal phases using in situ hybridization. Expression of mRNA encoding IGF-I showed a cyclical pattern, increasing sharply in the mucosa and muscularis during the late follicular phase $(P \leq 0.001)$, then declining. In the muscularis, mRNA encoding IGF-II exhibited no temporal changes, but concentrations in the mucosa increased from the late follicular stage to the early luteal phase. mRNA encoding the type I IGF receptor was present throughout the oviduct. Concentrations increased during the follicular phase to peak in the early luteal phase in both the mucosa and muscularis $(P<0.001)$. IGFBP-2 gene transcripts were undetectable at all time points examined. mRNAs encoding IGFBP-3 and IGFBP-4 were localized primarily in the stromal region. IGFBP-3 expression peaked in the late follicular stage of the cycle $P \leq 0.001$ ). The concentration of mRNA encoding IGFBP-4 increased in the follicular phase and was maintained at a significantly higher concentration during the early and mid-luteal stages $(P<0.001)$. The co-ordinate maximum expression of mRNA for both IGF-I and IGF-II, the type 1 IGF receptor and IGFBP-3 during the period when the gametes and embryo are in transit suggests a role for IGF-I and possibly IGF-II peptides in providing an oviductal environment propitious to conception and early embryonic growth and metabolism.
\end{abstract}

\section{Introduction}

Fertilization and early embryonic development take place in the oviduct. In sheep, the embryo travels through the oviduct during the first four cell cycles and enters the uterus 66-72 $\mathrm{h}$ after ovulation at the 8- to 16-cell stage (Hunter, 1988). This stage appears crucial in ovine embryo development as cultured embryos show a 'culture block' at this time (Bavister, 1988), possibly due to an environment unfavourable for the transition for maternal to embryonic genome usage (Telford et al, 1990). This block is reversible when fertilized eggs are co-cultured with oviduct cells (Gandolfi and Moor, 1987), suggesting that these are providing an environment more favourable to early embryonic development and viability than culture medium alone.

The insulin-like growth factors IGF-I and IGF-II are single chain polypeptide growth factors of approximate molecular mass $7.5 \mathrm{kDa}$, with a tertiary structure analogous to that of proinsulin (Daughaday and Rotwein, 1989). They stimulate a broad range of mitogenic and anabolic effects (for reviews see: Zapf and Froesch, 1986; Jones and Clemmons, 1995), through

*Correspondence.

Revised manuscript received 3 June 1996. binding to the type 1 IGF receptor, IGF-1R (for reviews see: Rechler and Nissley, 1985; LeRoith et al., 1995). Studies on the tissue distribution of IGF peptides and their mRNAs have confirmed that the insulin-like growth factors are synthesized at many extra-hepatic sites (Mathews et al., 1986, 1987), and have been identified in the uteri of a variety of species (rats: Murphy et al., 1987; pigs: Simmen et al., 1989; humans: Boehm et al., 1990; cows: Geisert et al., 1991; sheep: Stevenson et al., 1994).

Evidence for the synthesis of several growth factors in the oviduct has been demonstrated, including members of the epidermal growth factor (EGF) family and the transforming growth factor $\beta$ (TGF $\beta$ ) family (Dalton et al., 1994; Zhao et al., 1994), interleukins (Dalton et al., 1994), and the insulin-like growth factors and their binding proteins (Williams and Butler, 1991; Pfeifer and Chegini, 1994; Schmidt et al., 1994; Stevenson and Wathes, 1994). Several lines of evidence suggest a role for the insulin-like growth factors in the preimplantation period. Mammalian embryos investigated so far express mRNA for the IGFs, IGF receptors, and the insulin receptor from early development onwards (1- to 8-cell stage; for review see: Schultz and Heyner, 1993), and insulin-like growth factor peptides are present in uterine luminal fluid (pigs: Simmen et al., 
1989; cows: Geisert et al, 1991; sheep: Ko et al., 1991), and oviductal fluid (pigs: Wiseman et al., 1992) of several species. Rabbit embryos progress to the blastocyst stage when incubated with IGF-I (Herrler and Beier, 1994), and IGF-I and insulin both affect metabolism in early preimplantation mouse embryos (Gardner and Kaye, 1984; Harvey and Kaye, 1991).

We have shown previously that there is a substantial increase in mRNA encoding IGF-I in the ovine uterus around the time of ovulation (Stevenson et al., 1994; Wathes et al., 1994). In the present study we have investigated the spatial and temporal localization of mRNAs encoding IGF-I, IGF-II, IGF-IR, and IGF-binding proteins (IGFBP) $-2,-3$, and -4 in the ovine oviduct during the peri- and post-ovulatory periods.

\section{Materials and Methods}

\section{Animals}

Tissue samples were collected from 33 ewes of various breeds with an average oestrous cycle duration of 16-17 days. They were run with a vasectomized ram and raddle marks were checked daily to determine the day of oestrus (day 0 ). The animals were killed by anaesthetic overdose (Lethobarb; Duphar Veterinary Ltd, Southampton, Hants), and tissue samples were collected during the follicular phase at $36 \mathrm{~h}$ $(n=10), 48 \mathrm{~h}(n=2)$ and $60 \mathrm{~h}(n=2)$ after a mid-cycle injection of the prostaglandin $\mathrm{F}_{2 u}\left(\mathrm{PGF}_{2 u}\right)$ analogue cloprostenol (125 $\mu \mathrm{g}$ i.m. Estrumate; Cooper's Animal Health Ltd, Crewe, Cheshire) and during the luteal phase on days $2-3(n=3), 5(n=3), 9-10$ $(n=3)$ and $13(n=10)$ after natural oestrus. Animals in our flock usually come into oestrus about $48 \mathrm{~h}$ after a cloprostenol injection and ovulate about $65 \mathrm{~h}$ after treatment.

\section{Sample collection and storage}

The reproductive tract was removed immediately and the oviducts were dissected from surrounding connective tissue, wrapped in aluminium foil, and frozen in isopentane (Merck Ltd, Poole, Dorset) in liquid $\mathrm{N}_{2}$. Tissue samples were stored at $-80^{\circ} \mathrm{C}$ until used.

\section{Oligodeoxynucleotide probes}

The 45-base synthetic oligodeoxynucleotide probes for detection of mRNAs encoding IGF-I and IGF-II were provided by R. S. Gilmour (The Babraham Institute, Cambridge). The use of these two probes and that for detection of mRNA encoding IGF-IR have been described by Stevenson et al. (1994). The antisense oligodeoxynucleotide probe sequences used to localize mRNA encoding IGFBP-2, IGFBP-3, and IGFBP-4 in ovine oviductal tissue were CAG AGT GCT CCT CGC CAT TGT CTG CAA CCT GCT CGG GGC TGG CGC (antisense sequence to nucleotides 453-497 ovine IGFBP-2 gene; Delhanty and Han, 1992), GGC CTG GTT CTC TGT GCT CCC CAT GCT GTG GTC CTC CTC GCT CTC (antisense sequence to nucleotides 534-578 of the bovine gene (Spratt et al., 1991) adapted for best codon usage in sheep, selected in an area of sequences conserved between species but not between different IGFBPs) and GCC GCA GTC GGG GGT GTA CAC CCC ACA GCG CAT TCC CTT GCC CAG (sequence complementary to nucleotides 118-162 of the cDNA sequence for ovine IGFBP-4 from Carr et al., 1994), respectively. Sense oligodeoxynucleotide sequences to the corresponding antisense probes were used as controls for non-specific hybridization in all in situ hybridization experiments. All oligodeoxynucleotide probes were manufactured at the Microchemical Facility, The Babraham Institute, Cambridge.

\section{In situ hybridization}

The in situ hybridization technique used was as described by Stevenson et al. (1994). All chemicals were from Sigma Chemical Co. (Poole, Dorset) or Merck Ltd (Poole, Dorset) unless stated otherwise. In brief, $10 \mu \mathrm{m}$ sections were thawmounted onto RNAse-free poly-L-lysine subbed slides, fixed in $4 \%(\mathrm{w} / \mathrm{v})$ paraformaldehyde, dehydrated, and stored in $95 \%$ $(\mathrm{v} / \mathrm{v})$ ethanol at $4^{\circ} \mathrm{C}$ until used. The sections were hybridized overnight at $42^{\circ} \mathrm{C}$ with $100 \mu \mathrm{l}$ hybridization buffer containing 110000 d.p.m. oligodeoxynucleotide probe $3^{\prime}$ end-labelled with ${ }^{35}$ S-labelled dATP (Du Pont UK Ltd, Diagnostics and Biotechnology Systems, Stevenage, Herts) using terminal deoxynucleotide transferase (from calf thymus, FPLCpure ${ }^{\mathbf{K}}$; Pharmacia LKB Biotechnology, Milton Keynes, Bucks) in 50\% $(\mathrm{v} / \mathrm{v})$ deionized formamide, $4 \times \mathrm{SSC}(1 \times \mathrm{SSC}$ is $15 \mathrm{mmol} \mathrm{NaCl}$ $\mathrm{l}^{-1}, 15 \mathrm{mmol}$ sodium citrate $\left.\mathrm{l}^{-1}\right), 10 \%(\mathrm{w} / \mathrm{v})$ dextran sulphate, $5 \times$ Denhardt's solution, $0.2 \mathrm{mg}$ single-stranded salmon sperm DNA ml ${ }^{-1}, 0.2 \mathrm{mg}$ polyadenylic acid $\mathrm{ml}^{-1}, 0.12 \mathrm{mg}$ heparin $\mathrm{ml}^{-1}, 0.025 \mathrm{~mol}$ sodium phosphate $\mathrm{l}^{-1}$ (pH 7.0), $0.001 \mathrm{~mol}$ sodium pyrophosphate $1^{-1}$. After hybridization, slides were washed under low $\left(1 \times \mathrm{SSC}, 0.2 \%(\mathrm{w} / \mathrm{v}) \mathrm{NaS}_{2} \mathrm{O}_{3}, 30 \mathrm{~min}\right.$ at room temperature) and higher ( $1 \times \mathrm{SSC}, 0.2 \%(\mathrm{w} / \mathrm{v}) \mathrm{NaS}_{2} \mathrm{O}_{3}$, $60 \mathrm{~min}$ at $55^{\circ} \mathrm{C}$ ) stringency conditions, rinsed and dehydrated sequentially in $\mathrm{I} \times \mathrm{SSC}, 0.1 \times \mathrm{SSC}, 70 \%$ ethanol, and $95 \%$ ethanol for $20 \mathrm{~s}$ each.

The slides were exposed to Hyperfilm $\beta$-max (Amersham International plc, Amersham, Bucks) in X-ray cassettes to detect the hybridization signals for 10 days (IGF-I), I4 days (IGF-1R), 21 days (IGF-II and IGFBP-4) and 31 days (IGFBP-2 and IGFBP-3). Individual slides were subsequently dipped in photographic emulsion (LM-I; Amersham International plc), dried at room temperature for $2-4 \mathrm{~h}$, and exposed for 14 (IGF-1, IGF-IR), 21 (IGF-II), or 31 (IGFBPs) days at $4{ }^{\circ} \mathrm{C}$ in lighttight boxes containing silica gel. The slides were developed at room temperature in Phenisol (1:5; National Veterinary Supplies, Stoke-on-Trent, Staffs) for $5 \mathrm{~min}$, transferred to a stop bath $(2 \%(\mathrm{v} / \mathrm{v})$ acetic acid) for $5 \mathrm{~min}$, fixed for $10 \mathrm{~min}$ in $30 \%$ $(\mathrm{w} / \mathrm{v}) \mathrm{NaS}_{2} \mathrm{O}_{3}$, rinsed in distilled water and counterstained with haematoxylin and eosin.

\section{Absorbance measurements}

The quantification of the relative expression of components of the IGF system in ovine oviductal samples from $X$-ray film used an image analysis system (Seescan plc, Cambridge) as described by Stevenson et al. (1994). The imaging package calculates the average absorbance $(A)$ value over selected areas of the autoradiograph based on a linear grey scale of 0 to 2.I. The detection limit of this technique was taken as a reading of $\leq 0.01$. Between four and six pairs of antisense (AS) and sense 
Table 1. Temporal expression of mRNAs encoding the insulin-like growth factor (IGF) system in the ovine oviduct*

Peak expression of mRNAs encoding different components of the IGF system

\begin{tabular}{lcc}
\cline { 2 - 3 } & Mucosa & Muscularis \\
\hline IGF-I & $48-60 \mathrm{~h}$ after PG & $48-60 \mathrm{~h}$ after PG \\
IGF-II & No changes \\
IGF-1R & Days 2-3 & Days 2-3 \\
IGFBP-3 & $48-60 \mathrm{~h}$ after PG & $48-60 \mathrm{~h}$ after PG \\
IGFBP-4 & $48-60 \mathrm{~h}$ after PG to days 5-9 & $48-60 \mathrm{~h}$ after PG to days 5-9 \\
\hline
\end{tabular}

IGF-IR:type 1 IGF receptor. IGFBP: IGF binding protein. PG: cloprostenol injection.

*These observations were based on data from absorbance quantification of X-ray films following in situ hybridisation and report significant changes relating to Figs 3 and 6 . Significance values are given in the results. mRNA encoding IGFBP- 2 could not be detected at any time point.

(S) treatment and control sections from each animal were processed. Sections from adult liver and a uterus at oestrus were used as positive controls and the sections of uterus at oestrus were present in each experiment for comparison. Digital images of the autoradiographs were projected onto a VDU using a camera equipped with a zoom lens; the background of the film was subtracted from the captured image, and representative areas of the oviduct (as determined from haematoxylin- and eosin-coated slides) were outlined in each case. The regions examined were the mucosa and the muscle wall (muscularis) for the ampulla and the isthmus. The absorbance values from the $S$ sections were subtracted from the AS values to give an estimate of the specific hybridization in each region. Coefficients of variation for duplicate absorbance measurements using the various probes were as follows: IGF-I $12.3 \%$, IGF-II $21.2 \%$, IGF-IR $14.7 \%$, IGFBP-3 $10.9 \%$ and IGFBP-4 $9.3 \%$.

\section{Statistical analyses}

An initial analysis showed that data were not significantly different between the following pairs of time points: $48 \mathrm{~h}$ and $60 \mathrm{~h}$ after cloprostenol treatment (late follicular phase), days 2 and 3 (early luteal phase), and days 5 and 9 (mid-luteal phase). Hence, these time points were grouped for subsequent analysis to minimize the number of comparisons. Data were log transformed to achieve homogeneity of variance and were analysed using an unbalanced ANOVA design (Unistat 4.0) with time and region (ampulla or isthmus) as factors. Where significant time effects were demonstrated Neuman-Keuls tests were used to determine which time points differed.

\section{Results}

The temporal expression of mRNAs encoding the IGF system are summarized (Table 1).

\section{Distribution of $m R N A$ encoding IGF-I}

IGF-I gene transcripts were present in both the ampulla and the isthmus (Figs 1a and 2a). No significant differences in concentrations of mRNA encoding IGF-I were noted between regions (ampulla and isthmus), but transcript concentrations in the mucosa and muscle exhibited cyclical changes (ANOVA time effect $P<0.001$ in both compartments, Figs $3 \mathrm{a}$, d). Concentrations of mRNA encoding IGF-I in both compartments were basal in the late luteal phase (day 13; absorbance $\leq 0.01$ ), began to rise during the early follicular stage $36 \mathrm{~h}$ after cloprostenol treatment and peaked around the time of behavioural oestrus $48-60 \mathrm{~h}$ after cloprostenol treatment. Values then declined through the early and mid-luteal phase and returned to basal values by day 13 . Concentrations of mRNA encoding IGF-I were significantly higher before ovulation (48-60 h after cloprostenol treatment) than at any other stage investigated $(P \leq 0.001$; Figs $3 a, d)$. Cellular localization of the signal using emulsion-coated slides counterstained with haematoxylin and eosin showed that the IGF-I gene transcripts were localized predominantly to the stromal fibroblasts underlying the luminal epithelium in the mucosa (Fig. 4a), and to the smooth muscle cells of the muscle wall, in both the ampulla and the isthmus. Some grains were also visible on epithelial cells, but it was uncertain whether this was due to low expression or to scattering of signal within the emulsion. No signal was visible in the blood vessel walls.

\section{Distribution of mRNA encoding IGF-II}

The probe used to detect IGF-II gene transcripts showed strongest hybridization to the smooth muscle cells of the muscle wall of both the ampulla and the isthmus (Figs $1 \mathrm{~b}, 2 \mathrm{c}$ and $4 \mathrm{c}$ ), with low concentrations of mRNA encoding IGF-II in the mucosa. There were no significant differences in IGF-II gene transcript expression between the ampulla and isthmus. In the mucosa, there was a significant effect of time $(P<0.001$; Fig. 3b), with concentrations highest in the late follicular and early luteal stages. The pattern of change in the muscle wall was similar (Fig. 3e) but the differences were not significant. No mRNA encoding IGF-II was present in the blood vessel walls.

High concentrations of non-specific hybridization were noted in surrounding connective tissue (Fig. 2d); this may be due to the probes binding to eosinophils ( $G$. Morgan, unpublished observation seen in intestinal tissue), melanocytes 

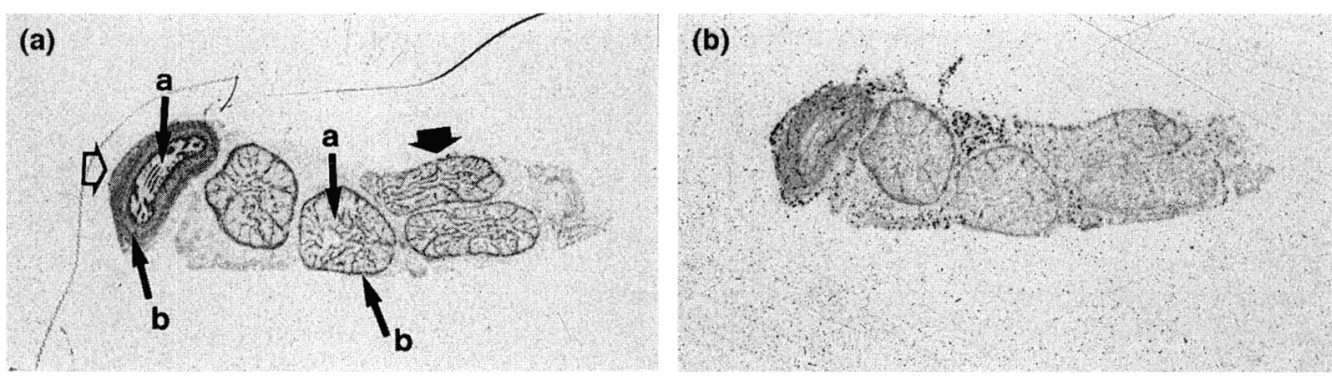

(c)

(d)
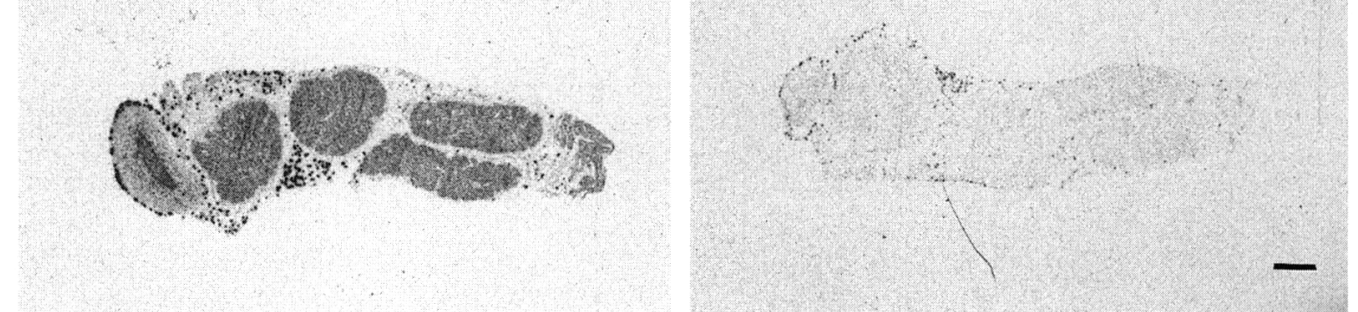

Fig. 1. Localization of mRNAs encoding: (a) insulin-like growth factor I (IGF-I); (b) IGF-II and (c) type 1 IGF receptor in the ovine oviduct shortly before ovulation. The sections depicted are serial sections from the same animal killed $60 \mathrm{~h}$ after cloprostenol injection, treated with the antisense oligodeoxynucleotide (a-c) to their respective gene. (d) A representative section treated with the IGF-I sense oligodeoxynucleotide showing the non-specific background hybridization (exposure 10 days). The regions illustrated in (a) are: open arrow: isthmus; filled arrow: ampulla; a: mucosa; b: muscle wall. Scale bar represents $1 \mathrm{~mm}$.

(Stevenson et al., 1994), or to lymphocytes infiltrating this tissue. This non-specific binding has previously been observed with all six probe types used in these investigations and probably becomes more noticeable when the $\mathrm{X}$-ray films are exposed for longer periods.

\section{Distribution of $m R N A$ encoding IGF-1R}

mRNA encoding IGF-TR was present in both the ampulla and the isthmus (Figs $1 \mathrm{c}$ and 2e). Hybridization was strongest to the epithelial cells of the mucosa (Fig. 4e), with transcripts also present in the smooth muscle cells of the muscle wall. In both the mucosal and muscular compartment of the ampulla and the isthmus, cyclical changes were apparent (time effects in the mucosa and muscularis $P<0.01$ and $P<0.001$, respectively). Lowest IGF-IR gene transcript values were measured on day 13 in both compartments (Figs $3 c$, $\mathrm{f}$ ), increased during the early and late follicular stages to peak concentrations on days $2-3$. Subsequently, values declined, but were still significantly higher on days 5-9 than in the late luteal stage.

\section{Distribution of $m R N A$ encoding IGFBP-2}

No hybridization for the IGFBP-2 probe was noted in the oviduct at any of the stages examined, although this probe detects transcripts in both the ovine ovary (Perks et al., 1994) and placenta (Reynolds et al., 1995).

\section{Distribution of $m R N A$ encoding IGFBP-3}

IGFBP-3 gene transcript was localized predominantly to the mucosal stroma and to the smooth muscle cells in the muscularis, in both the ampulla and isthmus (Figs $4 \mathrm{~g}$ and $5 \mathrm{c}$ ). No significant differences in concentration of mRNA encoding IGFBP-3 were noted between the ampulla and isthmus for either the mucosal or muscular compartments. However, temporal changes were such that transcript concentrations in both muscle and mucosa were highest at oestrus $(48-60 \mathrm{~h}$ after cloprostenol treatment; $P \leq 0.001$ in comparison with all other time points; Figs $6 \mathrm{a}, \mathrm{b}$ ). mRNA encoding IGFBP-3 was present throughout the rest of the cycle at constant, low values.

\section{Distribution of $m R N A$ encoding IGFBP-4}

mRNA encoding IGFBP-4 was present at low values in both the ampulla and the isthmus (Fig. 5a). The mRNA was present in stromal fibroblasts of the mucosa (Fig. 4i) and the smooth muscle cells of the muscle wall. No significant changes in the spatial localization of the gene transcript were noted between the ampulia and isthmus, but there was a significant effect of time ( $P \leq 0.001$ for both compartments). IGFBP-4 gene transcript concentrations were at, or below, the detection limit of our quantification method in both the late luteal and early follicular groups (absorbance $\leq 0.01$; Figs $6 \mathrm{c}$, d) but were detected in the late follicular, early luteal, and mid-luteal time points. Concentrations of mRNA encoding IGFBP-4 were not significantly different from each other at these time points in either the muscularis or the mucosa.

\section{Discussion}

The investigations presented here have confirmed the presence of mRNA encoding IGF-I, IGF-II and the type I IGF receptor in the oviduct, and describe for the first time the presence of 

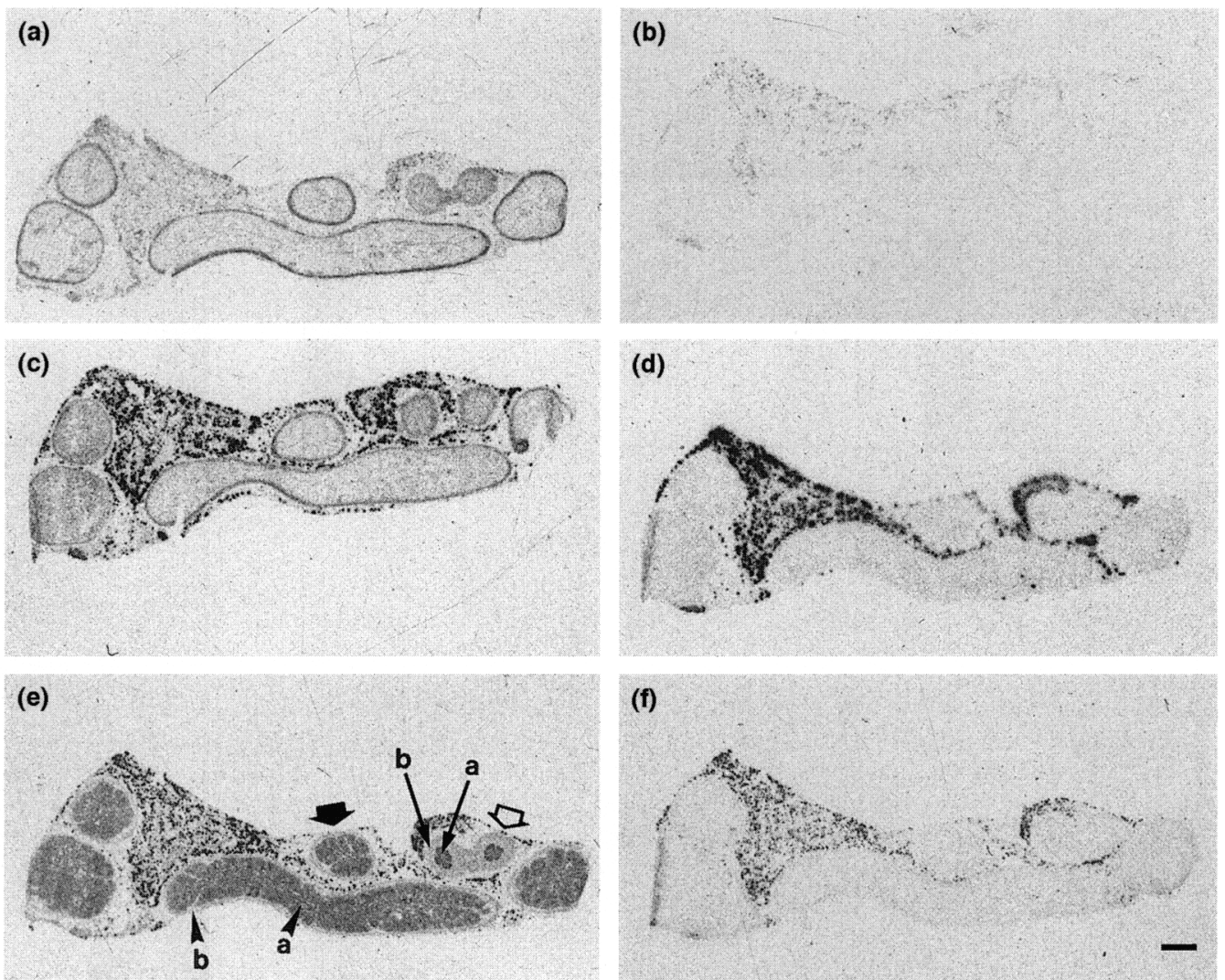

Fig. 2. Distribution of mRNAs encoding insulin-like growth factor I (IGF-I) and IGF-II, and type I IGF receptor (IGF-IR) in serial sections of an ovine oviduct in the early luteal phase. The antisense plates are: (a) mRNA encoding IGF-I, (c) mRNA encoding IGF-II, (e) mRNA encoding IGF-1R; (b, d, f) are corresponding sections treated with the sense probes. Note the high, non-specific background apparent in the surrounding connective tissue after $14(\mathrm{f})$ and $21(\mathrm{~d})$ days exposure in comparison with 10 days $(\mathrm{b})$. The regions illustrated in (e) are: open arrow: isthmus; filled arrow: ampulla; a: mucosa; b: muscle wall. Scale bar represents $1 \mathrm{~mm}$.

transcripts for the IGFBP-3 and IGFBP-4 genes in the ovine oviduct. Unlike previous reports for IGF peptides in the oviducts of sheep (Williams and Butler, 1991; Kincy et al., 1992; Watson et al., 1994) and other farm animal species (pigs: Wiseman et al., 1992; cows: Schmidt et al., 1994), this study has provided qualitative and quantitative data concerning the localization and abundance of mRNA encoding IGF system peptides within the oviduct during the period of time when the gametes are in transit.

IGF-I gene transcripts were localized mainly to the periepithelial stromal fibroblasts of the mucosa and smooth muscle cells of the muscle wall, in both the ampulla and the isthmus, at concentrations significantly higher before ovulation than in the early, mid- or late luteal phases. Increasing concentrations of mRNA encoding IGF-I were noted at a time of increasing oestradiol dominance suggesting that, as in the ovine uterus (Stevenson et al., 1994), oviductal IGF-I gene transcription is regulated by this steroid. Oestradiol regulation of IGF-I gene transcription has also been suggested for the oviduct of rats (Carlsson et al., 1993) and cows (Schmidt et al., 1994). Previous reports have detected mRNA encoding IGF-I in ovine oviductal epithelial cell cultures (Williams and Butler, 1991; Watson et al., 1994), suggesting that either the fainter signal localization we observed in the luminal epithelial cells was not due to scattering within the photographic emulsion, or that the epithelial cell cultures were contaminated with stromal fibroblasts. The temporal pattern of IGF-I gene transcription is in agreement with that reported for cows (Schmidt et al., 1994), and for IGF-I peptide concentrations in porcine oviductal fluid (Wiseman $e t$ al., 1992), both of which increased around the time of behavioural oestrus.

The localization of mRNA encoding IGF-I mainly in the stromal cells underlying the epithelial cells is not in agreement with IGF-I peptide localization using immunocytochemical methods in rats (Carlsson et al., 1993) and cows (Schmidt et al., 1994; Xia et al., 1996) in which the IGF-I peptide was found in the epithelial cells. This observation suggests either: (1) major differences between sheep and cows in the site of IGF-I gene transcription; (2) that the mRNA in the stromal cells is not translated, or (3) that the IGF-I peptide recognized by the immunocytochemical methods is secreted from the stromal cells and becomes bound to IGFBPs or IGF receptors on the epithelial cells. We consider the third option to be the most likely, as IGF type 1 receptors are located predominantly on the epithelial cells.

The main site of IGF-II gene transcription was the smooth muscle cells of the muscle wall in both the ampulla and the isthmus. This is in direct contrast to the situation in the uterine myometrium (Stevenson et al., 1994), in which very low to non-detectable values of IGF-II gene transcription were seen. 

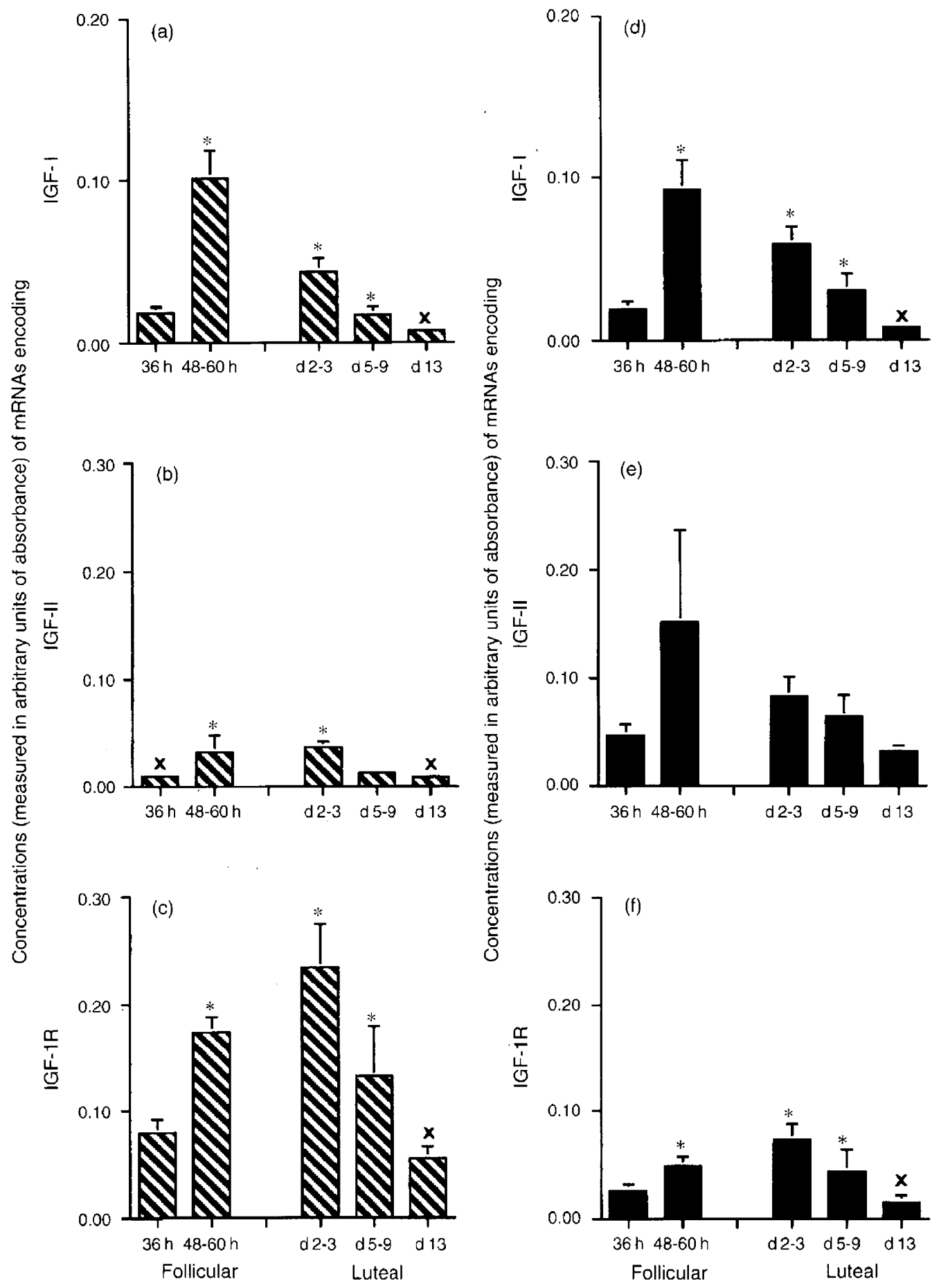

Stage of oestrous cycle

Fig. 3. Concentrations of mRNAs encoding ( $a, d)$ insulin-like growth factor I (IGF-I), (b, e) IGF-II and (c, f) type I IGF receptor $(I G F-I R)$ in the $(\mathbb{\$})$ mucosal $(a-c)$ and $(\boldsymbol{D})$ muscular $(d-f)$ compartments of the ovine oviduct during different stages of the oestrous cycle. Samples of oviduct were taken $36 \mathrm{~h}$ or $48-60 \mathrm{~h}$ after a mid-cycle injection of cloprostenol or 2-3,5-9 or 13 days after natural oestrus. Data from the ampullar and isthmic regions have been combined as they were not significantly different. Absorbances are given as the mean \pm SEM and are measurements (arbitrary units) from which non-specific sense readings have been subtracted. The limit of detection was taken as 0.01 units. Between three and nine animals were analysed at each time point. Note the differences in scale on the $y$ axes. Effects of time from the ANOVA analysis (performed on log transformed data) were as follows: (a-d) all $P<0.001$; (e) not significant and ( $\mathrm{f}) P<0.01$. The time of the lowest concentration is denoted with an $x$. All significant increases above this are labelled with an asterisk. 

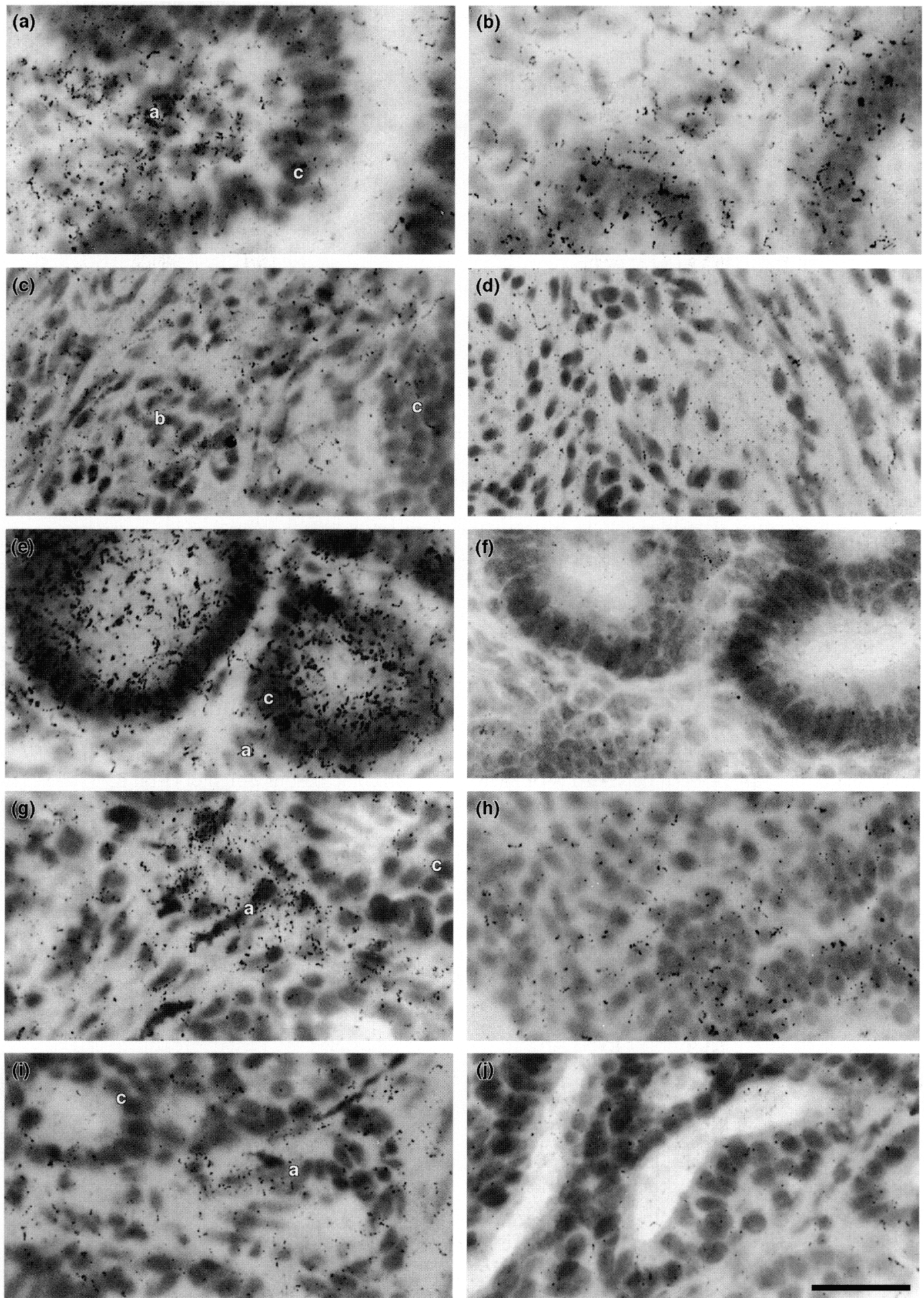

Fig. 4. Localization of mRNAs encoding ( $a, b$ ) insulin-like growth factor I (IGF-I); (c, d) IGF-II; (e, f) type 1 lGF receptor (IGF-1R); $(g, h)$ IGF binding protein 3 (IGFBP-3) and (i, j) IGFBP-4 in the ovine oviduct. (a, $c, e, g$, i) Sections treated with antisense probes. $(b, d, f, h, j)$ Serial sections treated with sense control probes showing non-specific background hybridization. All sections were from the ampulla of the same animal collected $48 \mathrm{~h}$ after cloprostenol injection (oestrus). The regions illustrated are: $a$ : mucosal stroma; $b$ : muscle wall and c: epithelium. (a) mRNA encoding IGF-I is predominantly localized to stromal fibroblasts. (c) mRNA encoding IGF-II was found mainly in the muscle wall. (e) mRNA encoding IGF-1R is principally in the epithelial cells. (g) mRNA encoding IGFBP-3 was found in scattered clumps within the mucosal stroma. (i) mRNA encoding IGFBP-4 was also located in the mucosal stroma. Scale bar represents $200 \mu \mathrm{m}$. 

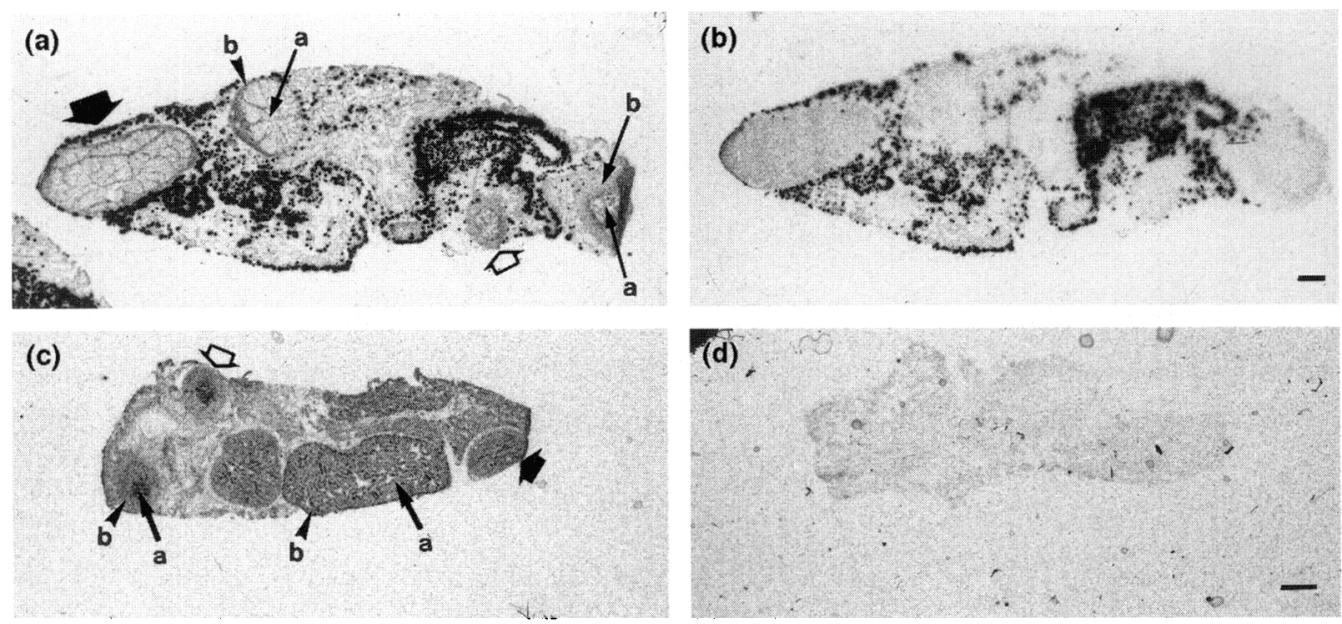

Fig. 5. Localization of mRNA encoding $(a, b)$ insulin-like growth factor binding protein 4 (IGFBP-4) and (c, d) IGFBP-3 in the ovine oviduct at oestrus. Sections in (b) and (d) are controls hybridized with sense probes for IGFBP-4 and IGFBP-3, respectively. The high non-specific background hybridization in the connective tissue in (b) after 31 days exposure that may be due to macrophage infiltration. The regions illustrated are: open arrow: isthmus; filled arrow: ampulla; a: mucosa; b: muscle wall. Scale bar represents $1 \mathrm{~mm}$.

Low levels of transcription were present in the stromal cells of the oviductal mucosa, with isthmic concentrations always greater than ampullar concentrations. This confirms the observations that mRNA encoding IGF-II is expressed by both ovine and bovine oviductal cells (Kincy et al., 1992; Xia et al., 1996). The translated gene product may be secreted into the oviductal fluid as an increase in IGF-II peptide content in porcine oviductal luminal fluid at oestrus has been described (Wiseman et al., 1992). The IGF-II peptide is probably acting through the type 1 IGF receptor (Moxham and Jacobs, 1992). The peak in oviductal mRNA encoding IGF-II seen in the late follicular and early luteal stages of the oestrous cycle is not seen in the uterus (Stevenson et al., 1994) and points to locally produced oviductal factors being responsible for its regulation.

Messenger RNA encoding the type I IGF receptor showed a distribution akin to that observed in the uterus, with transcript abundance greater in the secretory component than the muscle wall in both oviduct (this report) and uterus (Stevenson et al., 1994). As noted in the uterus, IGF-1R gene transcript concentrations in the epithelial cells of the mucosa increased during oestrus to peak in the early luteal phase, suggesting that the actions of the IGFs are primarily within the oviductal tissue, possibly to increase protein secretion into the oviduct lumen. This suggestion is supported by the increased secretory activity of the epithelial cells of the ovine oviduct that was observed between oestrus and day 3 of early pregnancy (Murray, 1995).

IGFBPs -1 to -4 and mRNA have been identified in human Fallopian tubes (Giudice et al., 1992; Pfeifer and Chegini, 1994), murine oviduct (Hahnel and Schultz, 1994), and the uteri of several species (cows: Geisert et al., 1991; rats: Girvigian et al., 1994; humans: Tang et al., 1994), and IGFBP-3 and -4 gene transcripts have now been documented in the ovine oviduct (this paper). The lack of mRNA encoding IGFBP-2 is in agreement with a similar lack of IGFBP-2 gene transcripts in the non-pregnant ovine uterus $(K$. R. Stevenson, unpublished observations). IGFBPs $-1,-5$, and -6 were not investigated here due to the lack of suitable probes. The presence of mRNA encoding IGFBP-3 and IGFBP-4 suggests paracrine or autocrine interactions within the oviduct. Although IGFBP-3 peptide is recognized as the prevailing IGFBP in the circulation, it is also synthesized at extra-hepatic sites, for example, the ovary (Nakatani et al., 1991) and would therefore be available in the extracellular fluid and the oviductal fluid to modulate IGF actions. The actions of IGFBP-3 on IGF-I effects would seem to be inhibitory in most systems (for reviews see: Rechler, 1993; Jones and Clemmons, 1995), though potentiating actions have been described. However, IGFBP-3 can associate with the cell surface (McCusker et al., 1991), possibly through an IGFBP-3 specific receptor which is different from the type I IGF receptor (Valentinis et al., 1995), to inhibit cell growth in an IGF-Iindependent manner. This illustrates the potential for action of IGFBP-3 without IGF-I having to be bound. Both IGFBP-3 and IGFBP-4 have specific serine proteases (IGFBP-3: Hossenlopp et al., 1990; IGFBP-4: Fowlkes and Freemark, 1992), increasing the complexity of the IGF system even further. The actions of IGFBP-4 are also predominantly inhibitory (for review see: Jones and Clemmons, 1995), but when subjected to proteolysis IGFBP-4 no longer binds IGF-I, possibly removing the inhibitory effect on IGF-I actions. The effects of IGFBPs on IGF action, and the involvement of cell membrane binding and proteolysis need to be elucidated further before speculation as to the possible contributions of IGFBPs in the oviduct is meaningful.

In conclusion, this investigation has illustrated that the ovine oviduct is a site of gene transcription for the type I IGF receptor gene and two of its ligands (IGF-I and IGF-II), and IGFBP-3, IGFBP-4 but not IGFBP-2. If transcript translation is a reflection of gene transcription, the spatial and temporal distributions described strongly suggest paracrine and autocrine interplay of the IGFs within the ovine oviduct around the time of behavioural oestrus, and we thus propose a role for these growth factors in a complex, possibly co-operative, interaction with other growth factors to provide an 

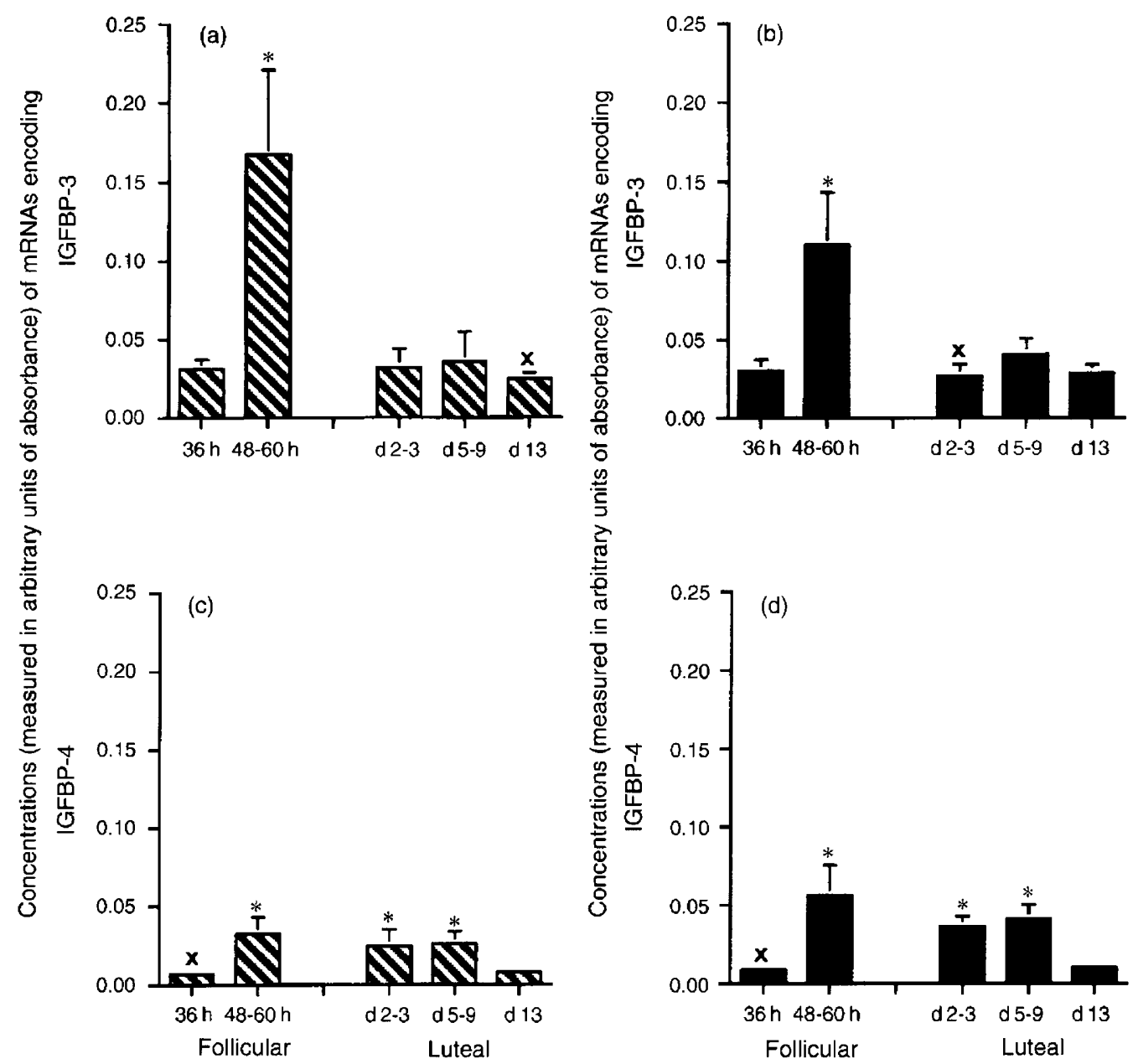

Stage of oestrous cycle

Fig. 6. Concentrations of mRNA encoding $(a, b)$ insulin-like growth factor binding protein 3 (IGFBP-3) and (c, d) IGFBP-4 in ( $\mathbf{N}$ ) the mucosal $(a, c)$ and $(\boldsymbol{\square})$ muscular $(b, d)$ compartments of the ovine oviduct during different stages of the oestrous cycle. Samples of oviduct were taken $36 \mathrm{~h}$ or $48-60 \mathrm{~h}$ after a mid-cycle injection of cloprostenol or 2-3,5-9 or 13 days after natural oestrus. Data from ampulla and isthmus were not significantly different and have been combined. Absorbances are given as mean \pm SEM, and are measurements (arbitrary units) from which non-specific sense readings have been subtracted. The limit of detection was taken as 0.01 units. Between three to eight animals were analysed at each time point. Effects of time from the ANOVA analysis (performed on log transformed data) were as follows: (a) $P<0.01$; (b) $P<0.05$; (c) $P<0.01$ and (d) $P<0.001$. The time of lowest concentration is labelled with an $\mathrm{x}$. All significant increases above this are shown with an asterisk. ( $a, b$ ) Concentrations of mRNA encoding IGFBP-3 peaked $48-60 \mathrm{~h}$ after the cloprostenol injection. (c, d) Concentrations of mRNA encoding IGFBP- 4 were raised $48-60 \mathrm{~h}$ after the cloprostenol injection, and days 2-3 and days 5-9 after oestrus in comparison with $36 \mathrm{~h}$ after the cloprostenol injection and day 13 after oestrus when values were below the detection limit of the quantification system.

environment advantageous for fertilization and early embryonic development.

The authors thank J. Thompson for care of the animals, P. J. Taylor and R. 1. Patman for the photography, and R. Scaramuzzi for the provision of some of the samples. The work was supported by BBSRC and the Wellcome Trust.

\section{References}

Bavister BD (1988) Role of oviductal secretions in embryonic growth in vitro and in vivo Theriogenology 29 143-155
Boehm KD, Daimon M, Gorodeski IG, Sheean LA, Utian WH and Ilan J (1990) Expression of the insulin-like and platelet-derived growth factor genes in human uterine tissues Molecular Reproduction and Development 27 93-101

Carlsson B, Hillsjö T, Nilsson A, Törnell J and Billig H (1993) Expression of insulin-like growth factor-1 (IGF-I) in the rat Fallopian tube: possible autocrine and paracrine action of Fallopian tube-derived IGF-I on the Fallopian tube and on the preimplantation embryo Endocrinology 133 2031-2039

Carr JM, Grant PA, Francis GL, Owens JA, Wallace JC and Walton PE (1994) Isolation and characterization of ovine IGFBP-4: protein purification and cDNA sequence Journal of Molecular Endocrinology 13 219-236

Dalton T, Kover K, Dey SK and Andrews GL (1994) Analysis of the expression of growth factor, interleukin-1, and lactoferrin genes and the distribution of inflammatory leukocytes in the preimplantation mouse oviduct Biology of Reproduction 51 597-606 
Daughaday WH and Rotwein P (1989) Insulin-like growth factors I and II. Peptide, messenger ribonucleic acid and gene structure, serum, and tissue concentrations Endocrine Reviews 10 68-91

Delhanty PJD and Han VKM (1992) The characterization and expression of ovine insulin-like growth factor-binding protein-2 Journal of Molecular Endocrinology $931-38$

Fowlkes J and Freemark M (1992) Evidence for a novel insulin-like growth factor (IGF)-dependent protease regulating IGF-binding protein- 4 in dermal fibroblasts Endocrinology 131 2071-2076

Gandolf F and Moor RM (1987) Stimulation of early embryonic development in the sheep by co-culture with oviduct epithelial cells Journal of Reproduction and Fertility $8123-28$

Gardner HG and Kaye PL (1984) Effects of insulin on preimplantation mouse embryos 16th Annual Meeting of the Australian Society of Reproductive Biology. Melbourne, Abstract P107

Geisert RD, Lee C-Y, Simmen FA, Zavy MT, Fliss AE, Bazer FW and Simmen RCM (1991) Expression of messenger RNAs encoding insulin-like growth factor-I, -II, and insulin-like growth factor binding protein-2 in bovine endometrium during the estrous cycle and early pregnancy Biology of Reproduction $\mathbf{4 5}$ 975-983

Girvigian MR, Nakatani A, Ling N, Shimasaki S and Erickson GF (1994) Insulinlike growth factor binding proteins show distinct patterns of expression in the rat uterus Biology of Reproduction 51 296-302

Giudice LC, Dsupin BA, Irwin JC and Eckert RL (1992) Identification of insulin-like growth factor binding proteins in human oviduct Fertility and Sterility 57 294-301

Hahnel A and Schultz GA (1994) Insulin-like growth factor binding proteins are transcribed by the preimplantation mouse embryo Endocrinology $\mathbf{1 3 4}$ $1956-1959$

Harvey MB and Kaye PL (1991) Mouse blastocysts respond metabolically to short term stimulation by insulin and IGF-I through the insulin receptor Molecular Reproduction and Development 29 253-258

Herrler A and Beier HM (1994) Influence of IGF-I on blastocyst formation in the rabbit Journal of Reproduction and Fertility Abstract Series 13 Abstract WI

Hossenlopp P, Sergovia B, Lassarre C, Roghani M, Bredon C and Binoux M (1990) Evidence of enzymatic degradation of insulin-like growth factor binding proteins (IGFBPs) in the $150 \mathrm{~K}$ complex during pregnancy Journal of Clinical Endocrinology and Metabolism 71 797-805

Hunter RHF (1988) The Fallopian Tubes: Their Roles in Fertility and Infertility. Springer Verlag, Berlin

Jones JI and Clemmons DR (1995) Insulin-like growth factors and their binding proteins: biological actions Endocrine Reviews 16 3-34

Kincy VL, Williams JE and Butler JE (1992) Expression of the insulin-like growth factor II (IGF-II) gene by ovine oviductal cells Biology of Reproduction 46 Supplement I, Abstract 68

Ko Y, Lee C-Y, Ott TL, Davis MA, Simmen RCM, Bazer FW and Simmen FA (1991) Insulin-like growth factors in sheep uterine fluids: concentrations and relationship to ovine trophoblast protein-1 production during early pregnancy Biology of Reproduction 45 135-142

LeRoith D, Werner H, Beitner-Johnson D and Roberts CT (1995) Molecular and cellular aspects of the insulin-like growth factor I receptor Endocrine Reviews $16143-163$

Mathews LS, Norstedt G and Palmiter RD (1986) Regulation of insulin-like growth factor 1 gene expression by growth hormone Proceedings of the National Academy of Sciences USA 83 9343-9347

McCusker RH, Camacho-Hubner C, Bayne ML, Cascieri MA and Clemmons DR (1991) Insulin-like growth factor (IGF) binding to human fibroblasts and glioblastoma cells: the modulating effect of cell released IGF binding proteins (IGFBPs) Journal of Cellular Physiology 144 244-253

Moxham C and Jacobs S (1992) Insulin-like growth factor receptors. In The Insulin-Like Growth Factors, Structure and Biological Function pp 80-109 Ed. PN Schofield. Oxford University Press, Oxford

Murphy LJ, Bell GI and Friesen HG (1987) Tissue distribution of insulin-like growth factor-I and -II messenger ribonucleic acid in the adult rat Endocrinology 120 1279-1282

Murray MK (1995) Epithelial lining of the sheep ampulla oviduct undergoes pregnancy-associated morphological changes in the secretory status and cell height Biology of Reproduction 53 653-663

Nakatani A, Shimasaki S, Erickson GF and Ling N (1991) Tissue-specific expression of four insulin-like growth factor binding proteins $(1,2,3$, and 4$)$ in the rat ovary Endocrinology 129 1521-1529
Perks CM, Stevenson KR and Wathes DC (1994) Localization of insulin-like growth factor binding proteins $2 \& 3$ (IGFBPs $2 \& 3$ ) in the ovine ovary Journal of Reproduction and Fertility Abstract Series 14 Abstract 4

Pfeifer TL and Chegini N (1994) Immunohistochemical localization of insulin-like growth factor (IGF-I), IGF-I receptor, and IGF binding proteins 1-4 in human Fallopian tube at various reproductive stages Biology of Reproduction $50281-289$

Rechler MM (1993) Insulin-like growth factor binding proteins Vitamins and Hormones 47 1-113

Rechler MM and Nissley SP (1985) The nature and regulation of the receptors for insulin-like growth factors Annual Review of Physiology 47 425-442

Reynolds TS, Perks CM, Stevenson KR and Wathes DC (1995) Expression of insulin-like growth factor II (IGF-II) mRNA and IGF binding protein-2 (IGFBP-2) mRNA during early placental development in the ovine uterus Journal of Endocrinology 147 (Supplement) P41

Schmidt A, Einspanier R, Amselgruber W, Sinowartz F and Schams D (1994) Expression of insulin-like growth factor I (IGF-I) in the bovine oviduct during the oestrous cycle Experimental Clinical Endocrinology 102 364-369

Schultz GA and Heyner S (1993) Growth factors in preimplantation embryos. Oxford Reviews of Reproductive Biology 15 43-82

Simmen FA, Simmen RCM, Letcher LR, Schober DA and Ko Y (1989) IGFs in pregnancy: developmental expression in uterus and mammary gland and paracrine actions during embryonic and neonatal growth. In Molecular and Cellular Biology of Insulin-like Growth Factors and their Receptors pp 195-208 Eds D LeRoith and MK Raizada. Plenum Publishing Corporation, New York

Spratt SK, Tatsuna GP and Sommer A (1991) Cloning and characterization of bovine insulin-like growth factor binding protein-3 (bIGFBP-3) Biochemical and Biophysical Research Communications 177 1025-1033

Stevenson KR and Wathes DC (1994) Spacial and temporal localization of insulin-like growth factors -I and -II (IGF-I, -II) and type I IGF receptor messenger ribonucleic acid in the ovine oviduct Journal of Reproduction and Fertility Abstract Series 13 Abstract 5

Stevenson KR, Gilmour RS and Wathes DC (1994) Localization of insulin-like growth factor-I (IGF-I) and -II messenger ribonucleic acid and type I receptor in the ovine uterus during the estrous cycle and early pregnancy Endocrinology 134 1655-1664

Tang X-M, Rossi MJ, Masterson BJ and Chegini N (1994) Insulin-like growth factor I (IGF-I), IGF-I Receptors, and IGF- binding proteins 1-4 in human uterine tissue: tissue localization and IGF-I action in endometrial stromal and myometrial smooth muscle cells in vitro Biology of Reproduction 50 $1113-1125$

Telford NA, Watson AJ and Schultz GA (1990) Transition from maternal to embryonic control in early mammalian development: a comparison of several species Molecular Reproduction and Development $2690-100$

Valentinis B, Bhala A, DeAngelis T, Baserga R and Cohen P (1995) The human insulin-like growth factor (IGF) binding protein-3 inhibits the growth of fibroblasts with a targeted disruption of the IGF-I receptor gene Molecular Endocrinology 9 361-367

Wathes DC, Perks CM and Stevenson KR (1994) Insulin-like growth factor-I (IGF-I) synthesis in the ovine reproductive tract: possible interactions between uterus and ovary 26 th Proceedings of the Australian Society of Reproductive Biology. Brisbane $\mathrm{p} 54$

Watson AJ, Watson PH, Arcellana-Panlilio M, Warnes D, Walker SK, Schultz GA, Armstrong DT and Seamark RF (1994) A growth factor phenotype map for ovine preimplantation development Biology of Reproduction 50 725-733

Williams JE and Butler JE (1991) Expression of insulin-like growth factor-1 (IGF-I) gene by ovine oviductal cells Journal of Animal Science 69 Supplement 1. Abstract 519

Wiseman DL, Henricks DM, Eberhardt DM and Bridges WC (1992) Identification and content of insulin-like growth factors in porcine oviductal fluid Biology of Reproduction 47 126-132

Xia P, Han VKM, Viuff D, Armstrong DT and Watson AJ (1996) Expression of insulin-like growth factors in two bovine oviductal cultures for embryo co-culture Joumal of Endocrinology 149 41-53

Zapf J and Froesch ER (1986) Insulin-like growth factors/somatomedins: structure, secretion, biological actions and physiological role Hormone Research 24 121-130

Zhao Y, Chegini N and Flanders KC (1994) Human Fallopian tube expresses transforming growth factor (TGF $\beta$ ) isoforms, TGF $\beta$ type I-III receptor messenger ribonucleic acid and protein, and contains [ ${ }^{125}$ I]TGF $\beta$-binding sites Journal of Clinical Endocrinology and Metabolism 79 1177-1184 